\title{
Surface analysis of latex and silicone pacifier nipples after exposure to acidic artificial saliva: a pilot study
}

Análise da superfície de bicos de chupeta de látex e sillicone após exposição à saliva artificial ácida: estudo piloto

Análisis de la superficie de los pezones de los chupetes de látex y silicona después de la exposición a saliva artificial ácida: un estudio piloto

\begin{abstract}
Objective: To measure surface changes of pacifier nipples after immersion in acidic artificial saliva. Methods: Two types of pacifier nipples (latex and silicone) were selected. Five copies of each type were used. The protocol consisted of immersion in acidic artificial saliva $(\mathrm{pH}=5.97)$ for 16 days. The nipples of the pacifier remained in direct contact with saliva in an individualized, opaque and closed container in a bacteriological incubator at $37^{\circ} \mathrm{C}$. The samples were examined before and after exposure to saliva through qualitative (based on images obtained in a $100 \mathrm{~mm}$ macro lens and three-dimensional images with $10 \%$ amplification obtained in the profilometry) and quantitative (roughness data obtained in non-contact 3D optical profilometry). Data were obtained in duplicate and analyzed using descriptive and inferential statistics. The findings were tested for normality (Shapiro-Wilk). Paired t-test or Wilcoxon was used to compare before and after roughness data. Results: In the image analysis, it was observed that only the surface of the latex pacifier's nipples showed an irregular appearance after exposure to saliva. In the quantitative evaluation, no differences were found between the roughness values before and after $(p>0.05)$. Conclusion: This pilot study demonstrated qualitative changes in the surface of latex pacifiers. However, it was not able to demonstrate statistically significant differences for the roughness parameters before and after exposure to acidic artificial saliva in the nipples of latex and silicone pacifiers.
\end{abstract}

Keywords: Pacifiers; Surface properties; Latex; Silicones.

\section{Resumo}

Objetivo: Medir alterações superficiais de bicos de chupeta após imersão em saliva artificial ácida. Metodologia: Dois tipos de bicos de chupeta (látex e silicone) foram selecionados. Cinco exemplares de cada tipo foram utilizados. O protocolo consistiu em imersão em saliva artificial ácida $(\mathrm{pH}=5,97)$ por 16 dias. A saliva foi trocada a cada 4 dias. Os bicos da chupeta permaneceram em contato direto com a saliva em recipiente individualizado, opaco e fechado na estufa a $37^{\circ} \mathrm{C}$. As amostras foram examinadas antes e após a exposição à saliva por meio da análise qualitativa (baseada em imagens obtidas em lente macro $100 \mathrm{~mm}$ e imagens tridimensionais com amplificação de $10 \%$ obtidas no 
perfilômetro) e quantitativa (dados de rugosidade obtidos na perfilometria óptica 3D de não contato). Os dados foram obtidos em duplicata e analisados por meio da estatística descritiva e inferencial. Os achados foram testados quanto à normalidade (Shapiro-Wilk). Teste t pareado ou Wilcoxon foi usado para comparar os dados de rugosidade antes e depois. Resultados: $\mathrm{Na}$ análise de imagens, observou-se que apenas a superfície dos bicos da chupeta de látex mostrou-se com aspecto irregular após a exposição à saliva. Na avaliação quantitativa, não se constatou diferenças entre os valores de rugosidade antes e após $(p>0,05)$. Conclusão: Este estudo piloto demonstrou alterações qualitativas na superfície dos bicos da chupeta de látex. Entretanto, não conseguiu demonstrar diferenças estatisticamente significativas para os parâmetros de rugosidade antes e após a exposição à saliva artificial ácida nos bicos das chupetas de látex e silicone.

Palavras-chave: Chupetas; Propriedades de superfície; Látex; Silicones.

\section{Resumen}

Objetivo: Medir los cambios superficiales de los pezones del chupete después de la inmersión en saliva artificial ácida. Métodos: Se seleccionaron dos tipos de chupetes (látex y silicona). Se utilizaron cinco copias de cada tipo. El protocolo consistió en inmersión en saliva artificial ácida $(\mathrm{pH}=5,97)$ durante 16 días. Los pezones del chupete permanecieron en contacto directo con la saliva en un recipiente individualizado, opaco y cerrado en una incubadora bacteriológica a $37^{\circ} \mathrm{C}$. En cada recipiente se dispensaron $40 \mathrm{ml}$ de saliva. Las muestras fueron examinadas antes y después de la exposición a la saliva a través de imágenes cualitativas (basadas en imágenes obtenidas en un lente macro de $100 \mathrm{~mm}$ e imágenes tridimensionales con $10 \%$ de amplificación obtenidas en la perfilometría) y cuantitativas (datos de rugosidad obtenidos en perfilometría óptica 3D sin contacto). Los datos se obtuvieron por duplicado y se analizaron mediante estadística descriptiva e inferencial. Se probó la normalidad de los hallazgos (Shapiro-Wilk). Se utilizó la prueba t pareada o Wilcoxon para comparar los datos de rugosidad antes y después. Resultados: En el análisis de la imagen, se observó que solo la superficie de los pezones del chupete de látex mostró un aspecto irregular después de la exposición a la saliva. En la evaluación cuantitativa, no se encontraron diferencias entre los valores de rugosidad antes y después ( $\mathrm{p}>0.05$ ). Conclusión: Este estudio piloto demostró cambios cualitativos en la superficie de los chupetes de látex. Sin embargo, no pudo demostrar diferencias estadísticamente significativas para los parámetros de rugosidad antes y después de la exposición a la saliva artificial ácida en los pezones de los chupetes de látex y silicona.

Palabras clave: Chupetes; Propiedades de superficie; Látex; Siliconas.

\section{Introduction}

The pacifier/dummy/soother use is related to several themes reported in literature. Main related themes with pacifier were breastfeeding; pain; sudden death and dental occlusion (Castilho \& Rocha, 2009). Much attention has been paid to the harmful effects of pacifier use on dental arches and malocclusion (Zhou et al., 2016). The focus on the interface between pacifier use and microbial colonization has attracted the attention of some scholars (Nelson-Filho et al., 2015). Some concerning findings have been reported in the literature. Some studies have investigated the effect of the pacifier use and the occurrence of several conditions.

One of them assessed the bacterial colonization of 40 rubber pacifiers of infants with acute otitis media (Brook $\&$ Gober, 1997). Other tested whether the use of the pacifier could be a risk factor for recurrent acute otitis media in children (Rovers et al. 2008) or for sharing an identical isolate from Haemophilus influenza among children at day-care centers (Barbosa-Cesnik et al., 2006).

Intestinal parasites may also be found in the surface of pacifiers. Eighty-six samples were assessed from children until the age of seven in a city in southeastern of Brazil and $11.63 \%$ presented eggs from of Ascaris lumbricoides, Enterobius vermicularis, Trichuris trichiura, Taenia sp and Ancylostomatidae larvae (Pedroso \& Siqueira, 1997). Additionally, the main perceptions of those responsible for the children indicate that the majority of them do not know or do not believe in the transmission of diseases through pacifiers (Pedroso \& Siqueira, 1997).

Literature points out that the prevalence of the pacifier use ranges from 25 to $50 \%$ (Rovers et al., 2008). Younger children frequently use more pacifiers than older children (Pedroso \& Siqueira, 1997; Rovers et al., 2008). Other study indicates a prevalence of $48 \%$ (Castilho, Casagrande, Rached, \& Nucci, 2012) while another work showed that the prevalence of pacifier use exclusively is $11.9 \%$ (Bezerra et al., 2019). Swedish infants used pacifier in a percentage varying from 3.2 to $15.4 \%$ (Arrts, Hörnell, Kylberg, Hofvander, \& Gebre-Medhin, 1999). Moreover, the pacifier use at naptime and bedtime was 
encouraged on a document for recommendations for a safe infant sleeping environment (Moon \& AAP TASK FORCE ON SUDDEN INFANT DEATH SYNDROME, 2016). The decision whether or not to include a pacifier in infant life belongs to the family. Health professionals should provide parents clear information from negative aspects to expected desirable effects of pacifiers (Castilho \& Rocha, 2009).

Since the nipple portion of the pacifier can act as potentially pathogenic microorganisms reservoir and latex and silicone are frequent materials employed in this device (Comina et al., 2006; Silveira, Charone, Maia, Soares, \& Portela, 2009; Castilho \& Rocha, 2009) and above a delimited threshold rougher surfaces stimulate microbial adhesion/colonization of silicone and restorative materials (Tang et al., 2008; Yuan et al., 2016), the aim of this work is to conduct a pilot study to assess the effect of acidic saliva over surface wear from latex and silicone nipple pacifier in vitro.

\section{Methodology}

\subsection{Study design}

This laboratorial study included 10 samples of pacifiers. This study included two types of pacifiers according to the material used in the nipple part of this device. Latex and silicone pacifier nipples were selected. Both with nipple size 2 (this size is designed for children between 7 months to approximately 18 months) (Comina et al., 2006). Samples were purchased by the same examiner. Latex pacifier nipples were purchased in the city of São Paulo while silicone ones were obtained in the city of João Pessoa. The cost of the silicone specimens equivalent to 6.10 times the latex ones. Previous to the beginning of the experiments, the samples were kept at room temperature and protected from light. A convenience sample of five copies of each substratum was used.

\subsection{Pilot protocol}

The pilot protocol consisted of immersion (40ml/sample) in artificial acidic saliva (prepared in a local compound pharmacy in João Pessoa, Paraíba, Brasil) $\mathrm{pH}=5.97$ for 16 days in bacteriological incubator at $37^{\circ} \mathrm{C}$. The saliva solution was replaced every 4 days. The nipples of the pacifier remained in direct contact with saliva in an individualized, opaque and closed container. After the 16 days-period, the samples were immersed in distilled water (100ml/sample) in an individualized container for 1 hour at room temperature. Then, the substrates were dried at room temperature for 24 hours until the analysis. The current authors elaborated the protocol presented herein.

\subsection{Surface wear evaluation}

Two analyses were conducted. Qualitative and quantitative investigations. The qualitative evaluation covers image assessment obtained through a $100 \mathrm{~mm}$ macro lens; 1/100; F18 and ISO 100 and 10\% amplification three-dimensional qualitative image obtained through the profilometer. Both performed by the same assessor. Roughness data was obtained by a $3 \mathrm{D}$ non-contact profilometer with the following settings: low reflectance rough; $50 \mathrm{x}$ lens; 'xyz' mode and optimized resolution. The following 2D roughness parameters were used Ra; Rq; Rv, Rc and Rp (ISO 4287). Eight linear traces (336 $\mu \mathrm{m}$ ) were conducted in two areas of the sample (three vertical lines equidistant itself; three horizontal lines equidistant itself and two diagonals were performed in each area). $\mathrm{Ra}$ is an arithmetic average height parameter and is used in many studies. Rq is the standard deviation of the distribution of surface heights. Rv is the maximum depth of the profile below the mean line. Rc is the mean height of the roughness profile elements and $\mathrm{Rp}$ is the maximum height of the profile above the mean line (Gadelmawla, Koura, Maksoud, Elewa, \& Soliman, 2002). All data was obtained in duplicate. 


\subsection{Statistical analysis}

All measures were inserted into an electronic spreadsheet and mean values were obtained. The normality of data of each specific parameter was checked by Shapiro-Wilk test. Qualitative data was analyzed descriptively. To compare the roughness values at baseline from latex and silicone groups, $t$ test or Mann-Whitney test was used. To analyze the roughness data before and after the immersion in saliva solution, t-paired test or Wilcoxon test was used. All statistical analysis was conducted by the same researcher. A p-value of $<0.05$ was considered to be statistically significant.

\section{Results}

According to the images assessment, the latex samples exposed to acidic saliva presented a clear uneven appearance in contrast to silicone slabs that showed an unchanged surface after contact with current saliva solution (Figure 1A-D and Figure 2A-D). Quantitative profilometric evaluation demonstrated that roughness values from all assessed parameters (Ra; Rq; $\mathrm{Rv}$; Rc; Rp) were significantly greater in latex samples compared to silicone ones in baseline (Table 1). The paired analysis showed that exposure of the latex and silicone specimens to the acidic saliva did not result in surface wear (Table 2).

Figure 1A-D: Images analysis obtained by $100 \mathrm{~mm}$ macro lens. A) Baseline latex pacifier qualitative aspect. B) Latex pacifier aspect after the pilot experiment. C) Baseline silicone pacifier qualitative characteristics. D) Silicone pacifier aspect after the pilot experiment.

A

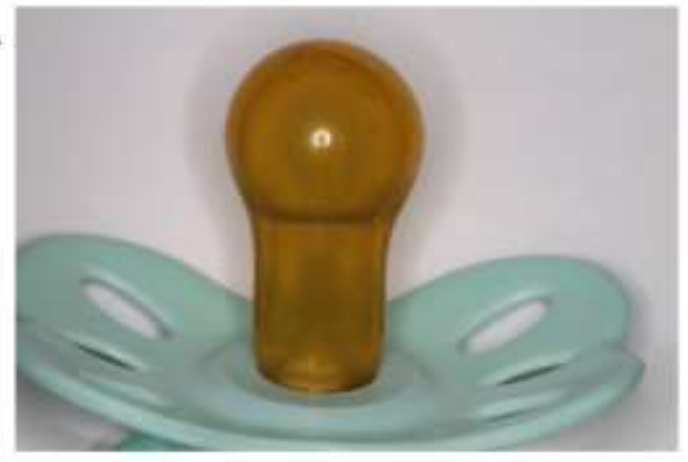

C

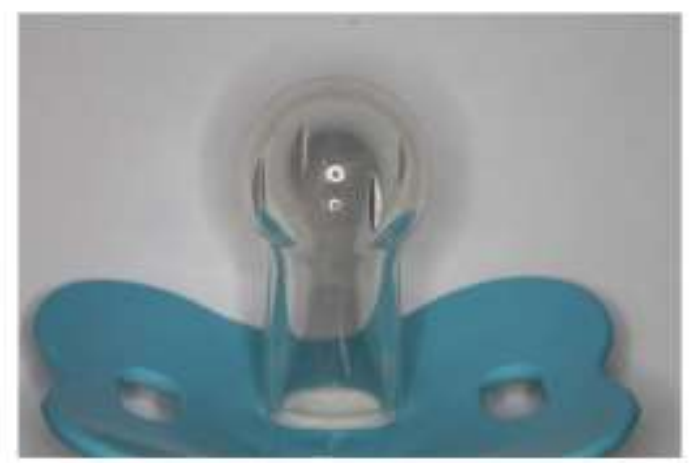

B

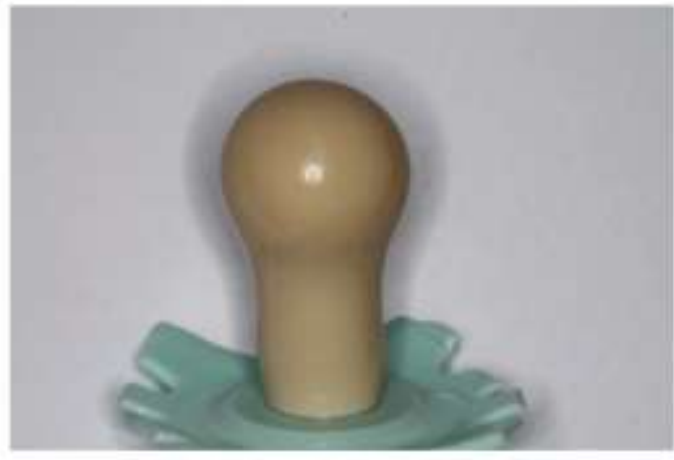

D

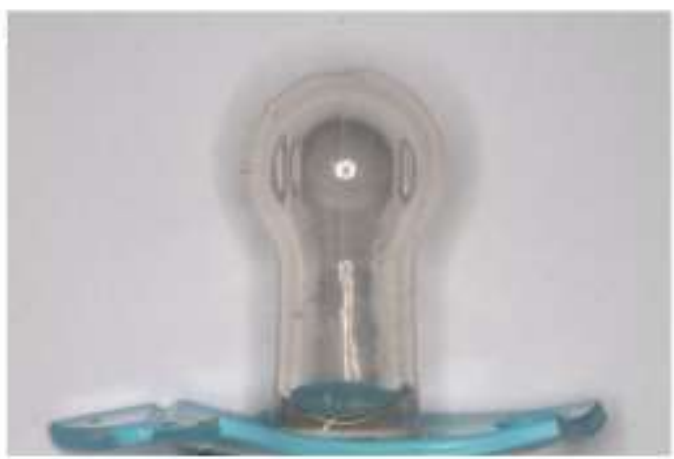

Source: Authors. 
Figure 2A-D: Images analysis obtained by 3D non-contact profilometer. A) Baseline latex pacifier qualitative profile. B) Latex pacifier profile after the pilot experiment. C) Baseline silicone pacifier qualitative profile. D) Silicone pacifier profile after the pilot experiment.

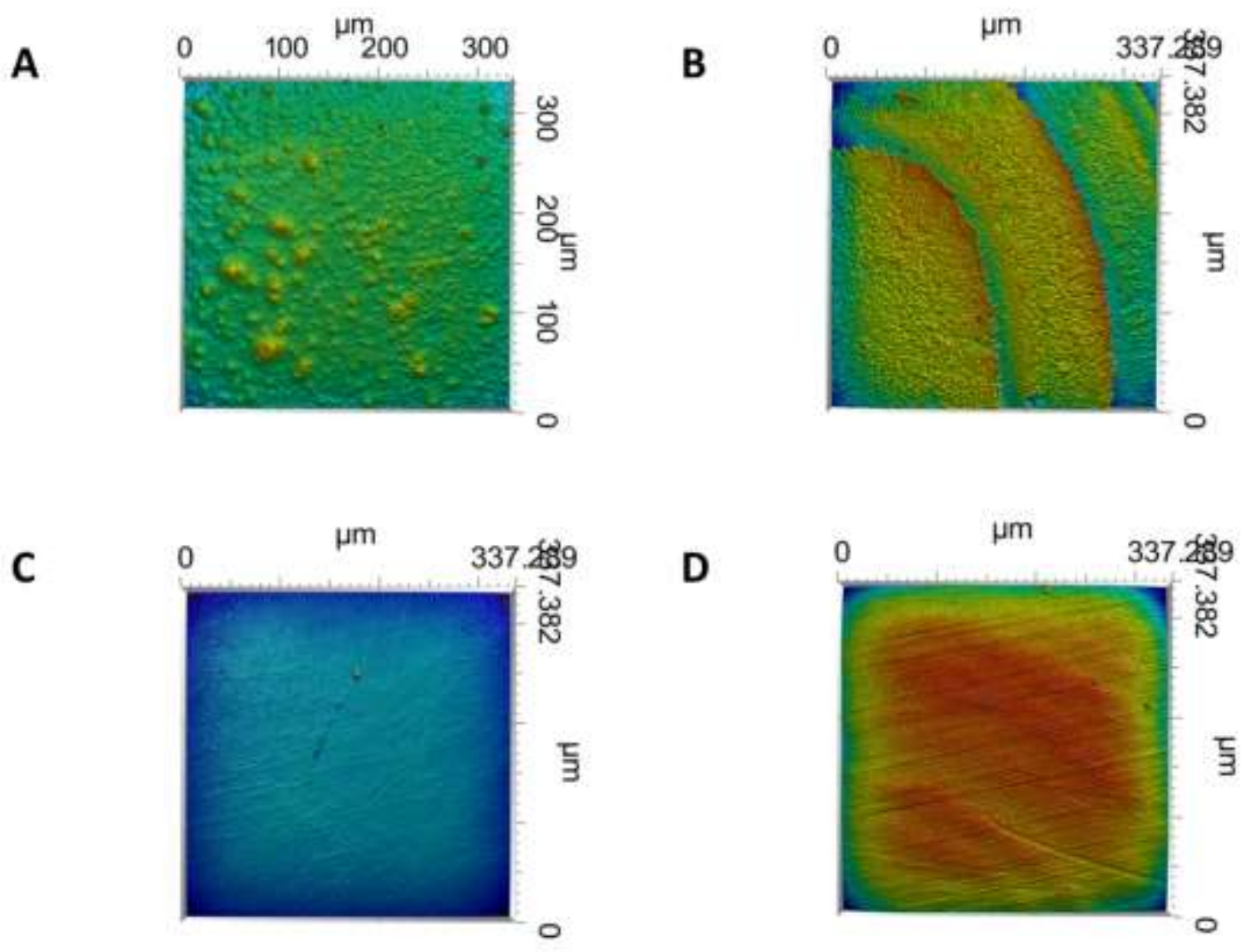

Source: Authors.

Table 1: Baseline roughness values $(\mu \mathrm{m})$ of the current sample.

\begin{tabular}{cccc}
\hline Roughness & \multicolumn{2}{c}{ Baseline (Median; Mean \pm SD) } & \\
\cline { 2 - 3 } parameter & Latex & Silicone & \\
\hline Ra & $0.09 ; 0.12 \pm 0.05^{\mathrm{A}}$ & $0.02 ; 0.03 \pm 0.01^{\mathrm{B}}$ & $\mathrm{p}<0.05^{¥}$ \\
$\mathrm{Rq}$ & $0.14 ; 0.18 \pm 0.08^{\mathrm{A}}$ & $0.03 ; 0.04 \pm 0.02^{\mathrm{B}}$ & $\mathrm{p}<0.05^{¥}$ \\
$\mathrm{Rv}$ & $0.33 ; 0.39 \pm 0.29^{\mathrm{A}}$ & $0.08 ; 0.09 \pm 0.03^{\mathrm{B}}$ & $\mathrm{p}<0.05^{\Phi}$ \\
$\mathrm{Rc}$ & $0.55 ; 0.72 \pm 0.57^{\mathrm{A}}$ & $0.12 ; 0.17 \pm 0.11^{\mathrm{B}}$ & $\mathrm{p}<0.05^{\Phi}$ \\
$\mathrm{Rp}$ & $0.53 ; 0.63 \pm 0.33^{\mathrm{A}}$ & $0.10 ; 0.15 \pm 0.13^{\mathrm{B}}$ & $\mathrm{p}<0.05^{\Phi}$
\end{tabular}

¥t test; $\Phi$ Mann-Whitney. Distinct superscript capital letters in line indicate statistical difference for each roughness parameter. Source: Authors. 
Table 2: Roughness values $(\mu \mathrm{m})$ of the current pacifiers' nipples before and after the exposition to acidic saliva.

\begin{tabular}{ccccc}
\hline Material & $\begin{array}{c}\text { Roughness } \\
\text { parameter }\end{array}$ & $\begin{array}{c}\text { Baseline } \\
(\text { Median; Mean } \pm \text { SD })\end{array}$ & $\begin{array}{c}\text { After } \\
(\text { Median; Mean } \pm \text { SD })\end{array}$ & $\mathrm{p}$-value \\
\hline Latex & $\mathrm{Ra}$ & $0.09 ; 0.12 \pm 0.05^{\mathrm{A}}$ & $0.12 ; 0.13 \pm 0.03^{\mathrm{A}}$ & $\mathrm{p}>0.05^{\ddagger}$ \\
& $\mathrm{Rq}$ & $0.14 ; 0.18 \pm 0.08^{\mathrm{A}}$ & $0.15 ; 0.16 \pm 0.05^{\mathrm{A}}$ & $\mathrm{p}>0.05^{\ddagger}$ \\
& $\mathrm{Rv}$ & $0.33 ; 0.39 \pm 0.29^{\mathrm{A}}$ & $0.43 ; 0.44 \pm 0,09^{\mathrm{A}}$ & $\mathrm{p}>0.05^{\S}$ \\
& $\mathrm{Rc}$ & $0.55 ; 0.72 \pm 0.57^{\mathrm{A}}$ & $0.52 ; 0.49 \pm 0.12^{\mathrm{A}}$ & $\mathrm{p}>0.05^{\S}$ \\
& $\mathrm{Rp}$ & $0.53 ; 0.63 \pm 0.33^{\mathrm{A}}$ & $0.55 ; 0.53 \pm 0.13^{\mathrm{A}}$ & $\mathrm{p}>0.05^{\ddagger}$ \\
\hline Silicone & $\mathrm{Ra}$ & $0.02 ; 0.03 \pm 0.01^{\mathrm{A}}$ & $0.02 ; 0.02 \pm 0.00^{\mathrm{A}}$ & $\mathrm{p}>0.05^{¥}$ \\
& $\mathrm{Rq}$ & $0.03 ; 0.04 \pm 0.02^{\mathrm{A}}$ & $0.03 ; 0.03 \pm 0.00^{\mathrm{A}}$ & $\mathrm{p}>0.05^{¥}$ \\
& $\mathrm{Rv}$ & $0.08 ; 0.09 \pm 0.03^{\mathrm{A}}$ & $0.09 ; 0.08 \pm 0.02^{\mathrm{A}}$ & $\mathrm{p}>0.05^{¥}$ \\
& $\mathrm{Rc}$ & $0.12 ; 0.17 \pm 0.11^{\mathrm{A}}$ & $0.07 ; 0.07 \pm 0.01^{\mathrm{A}}$ & $\mathrm{p}>0.05^{¥}$ \\
& $\mathrm{Rp}$ & $0.10 ; 0.15 \pm 0.13^{\mathrm{A}}$ & $0.07 ; 0.08 \pm 0.02^{\mathrm{A}}$ & $\mathrm{p}>0.05^{\S}$ \\
\hline
\end{tabular}

¥t-paired test; §Wilcoxon text. Distinct superscript capital letters in line indicate statistical difference. Source: Authors.

\section{Discussion}

This study was designed as a pilot study to assess the effect of acidic saliva over surface wear of latex and silicone pacifier nipples in vitro. Moreover, this is the first study in which two types of pacifier nipples were assessed qualitatively and quantitatively in relation to surface wear. The current work demonstrated qualitative changes in the surface of latex pacifier nipples after immersion in acidic saliva solution. However, no alterations were observed between baseline and 16 days-period roughness data after the contact with acidic saliva on both substrates.

Previous laboratorial study analyzed the biofilm of Candida species formed over the surface of latex and silicone nipple pacifier. The samples were evaluated by scanning electron microscopy. As expected, latex surface showed to be rougher than silicone ones (Silveira et al., 2009). The same finding was found in the present work. The main difference is that that study (Silveira et al., 2009) qualitatively assessed the nipples by scanning electron microscopy. In contrast, the current study adopted a qualitative and a quantitative evaluation by $3 \mathrm{D}$ non-contact profilometer.

One clinical study assessed the pacifier use after 16 weeks by healthy children (aged $1-24$ months) and observed by scanning electron microscopy that silicone pacifiers surface remained unchanged after the evaluated time period while the latex ones presented a rougher surface profile (Sio, Minwalla, George, \& Booth, 1987). Scanning electron micrographs also showed this distinction regarding the surface of the latex and silicone nipple pacifier. Again, latex samples seem to be more texturized at baseline (Comina et al., 2006). These results are similar to the findings reported herein.

Temperature may play an important role in the latex degradation (Isa, Yahya, Hassan, \& Tahir, 2007). The influence of temperature and reaction time in the degradation of natural rubber latex was analyzed in two distinct temperatures (60 and $70^{\circ} \mathrm{C}$ ). It was observed that subproducts containing epoxyl and hydroxyl groups were found and the rate of degradation depends on temperature and reaction time (Isa et al., 2007). The chemical agent also seems to be an important agent (Isa et al., 2007). The degradation at $30^{\circ} \mathrm{C}$ using periodic acid has been already reported (Phinyocheep, Phetphaisit, Derouet, Campistron, $\&$ Brosse, 2005). The latex samples seemed to be more affected to temperature of $37^{\circ} \mathrm{C}$ as well as the acidic saliva solution than the silicone ones during the 16 days of experiment. This may explain the qualitative results. However, this effect was not expressive enough to be detected at roughness evaluation.

Another analysis should be done within the limitations of the current study. A cost analysis should be taken into 
consideration. The pacifiers with the nipple part made of latex rubber were cheaper compared to silicone ones. One may suppose that the findings reported here may expose the population that bought this low cost device to the undesirable effects of pacifier wear. Previous clinical study had already demonstrated that latex pacifier nipples were more contaminated than silicone ones. Moreover, Candida genus was found only on the surface of the latex pacifier nipples (Comina et al., 2006).

This is the first study in which pacifier nipples samples were assessed regarding surface wear promoted by artificial acidic saliva in vitro. This pilot study was set up in order to mimic a possible oral condition regarding the use of pacifier (acidic saliva observed in children with active caries lesions (Pyati, Kumar, Kumar, Kumar, \& Reddy, 2018) or pH fluctuations observed in the mouth environment exposed to demineralization and remineralization cycles). A shortfall observed herein is the inability to simulate a physical interaction (Schlueter et al., 2020) which is expected along with the pacifier use. Another limitation is that infants do not use pacifier 24 hours per day uninterruptedly. In other words, it means to say that the saliva would not be in contact with the pacifiers uninterruptedly as presented here.

The pilot protocol described herein did not provoke roughness alteration on the surface of the pacifier nipples after the exposure to acidic saliva. The authors believe that more samples per group and a more acidic solution and a longer period of exposure would be recommended to observe any quantitative difference between the roughness parameters. Thus, future studies would be necessary to detect quantitatively the effect of the acidic saliva on surface wear of the present samples.

As far as we are concerned, there are not available studies assessing the surface roughness of pacifiers nipples in vitro. The surface characteristics, especially roughness profile, are related to more colonization of microorganisms (Tang et al., 2008; Yuan et al., 2016). This phenomenon can be explained by the increased surface area in the interface between surface material and microorganisms (Sterzenbach, Helbig, Hannig, \& Hannig, 2020). Moreover, surface topography may explain biofilm development since advantageous retentive places are found to be protective against dislodgment of the microbial cell arrangement (Park, Song, Jung, Ahn, \& Ferracane, 2012). Ra and Rq parameters are the main assessments in relation to cell adhesion in biological field (Anselme et al., 2010). The current experiment adopted the following parameter such as Rv, Rc and $\mathrm{Rp}$, in addition to $\mathrm{Ra}$ and $\mathrm{Rq}$ parameters. Despite the aim of the present study was not related to microorganisms' development, the present work brings light to the roughness values from the current samples.

\section{Conclusion}

In summary, the results of this pilot study show that latex pacifier nipples were affected qualitatively by acidic saliva solution in vitro. Latex nipple pacifiers are rougher than silicone ones. Roughness values from all assessed parameters (Ra; Rq; $\mathrm{Rv}$; Rc; Rp) were not different from baseline and 16 days-period after the experiment.

\section{Acknowledgments}

Thiago Isidro Vieira is a post-doctorate researcher in Post-Graduate Program in Dentistry at Universidade Federal da Paraíba and is supported by CAPES (Coordination for the Improvement of Higher Education Personnel), Ministry of Education, Brazil. This study was financed in part by the Coordenação de Aperfeiçoamento de Pessoal de Nível Superior Brasil (CAPES) - Finance code 001.

\section{References}

Aarts, C., Hörnell, A., Kylberg, E., Hofvander, Y., \& Gebre-Medhin, M. (1999). Breastfeeding Patterns in Relation to Thumb Sucking and Pacifier Use. Pediatrics, 104(4), e50.

Anselme, K., Davidson, P., Popa, A. M., Giazzon, M., Liley, M., Ploux, L. (2010). The interaction of cells and bacteria with surfaces structured at the nanometre scale. Acta Biomaterialia, 6(10), 3824-3846. 
Barbosa-Cesnik, C., Farjo, R. S., Patel, M., Gilsdorf, J., McCoy, S. I., Pettigrew, M. M., Marrs, C., Foxman, B. (2006). Predictors for Haemophilus influenzae Colonization, Antibiotic Resistance and for Sharing an Identical Isolate Among Children Attending 16 Licensed Day-Care Centers in Michigan. The Pediatric Infectious Disease Journal, 25(3):219-23.

Bezerra, V. M., Magalhães, E. I. S., Pereira, I. N., Gomes, A. T., Netto, M. P., Rocha, D. S. (2019). Prevalência e fatores determinantes do uso de chupetas e mamadeiras: um estudo no sudoeste baiano. Revista Brasileira de Saúde Materno Infantil, 19(2), 323-333.

Brook, I., \& Gober, A. E. (1997). Bacterial colonization of pacifiers of infants with acute otitis media. The Journal of Laryngology and Otology, 111(7):614-5.

Castilho, S. D., \& Rocha, M. A. M. (2009). Pacifier habit: history and multidisciplinary view. Jornal de Pediatria (Rio J), 85(6), 480-9.

Castilho, S. D., Casagrande, R. C., Rached, C. R., \& Nucci, L. B. (2012). Prevalence of pacifier among breastfed and not breastfed infants attending a university hospital. Revista Paulista de Pediatria, 30(2), 166-72.

Comina, E., Marion, K., Renaud, F. N. R., Dore, J., Bergeron, E., Freney, J. (2006). Pacifiers: A microbial reservoir. Nursing \& Health Sciences, 8(4), 216-23.

Gadelmawla, E. S., Koura, M. M., Maksoud, T. M. A., Elewa, I. M., \& Soliman, H. H. (2002). Roughness parameters. Journal of Materials Processing Technology, 123, 133-145.

Isa, S. Z., Yahya, R., Hassan, A., \& Tahir, M. (2007). The influence of temperature and reaction time in the degradation of natural rubber latex. The Malaysian Journal of Analytical Sciences, 11(1), 42-7.

Moon, R. Y., \& AAP TASK FORCE ON SUDDEN INFANT DEATH SYNDROME. (2016). SIDS and Other Sleep-Related Infant Deaths: Evidence Base for 2016 Updated recommendations for a Safe Infant Sleeping Environment. Pediatrics, 138(5), e20162940.

Nelson-Filho, P., Louvain, M. C., Macari, S., Lucisano, M. P., Silva, R. A. B., Queiroz, A. M., Gaton-Hernández, P., Silva, L. A. B. (2015). Microbial contamination and disinfection methods of pacifiers. Journal of Applied Oral Science, 23(5):523-8.

Park, J. W., Song, C. W., Jung, J. H., Ahn, S. J., \& Ferracane, J. L. (2012). The effects of surface roughness of composite resin on biofilm formation of streptococcus mutans in the presence of saliva. Operative Dentistry, 37(5), 532-539.

Pedroso, R. S., \& Siqueira, R. V. (1997). A study on protozoan cysts, helminth eggs and larvae in pacifiers. Jornal de Pediatria (Rio J), 73(1), 21-5.

Phinyocheep, P., Phetphaisit, C. W., Derouet, D., Campistron, I., \& Brosse, J. C. (2005). Chemical degradation of epoxidized natural rubber using periodic acid: preparation of epoxidized liquid natural rubber. Journal of Applied Polymer Science, 95, 6-15.

Pyati, S. A., Kumar, R. N., Kumar, V., Kumar, N. H. P., \& Reddy, K. M. P. (2018). Salivary flow rate, pH, buffering capacity, total protein, oxidative stress and antioxidant capacity in children with and without dental caries. The Journal of Clinical Pediatric Dentistry, 42(6), 445-449.

Rovers, M. M., Numans, M. E., Langenbach, E., Grobbee, D. E., Verheij, T. J. M., Schilder, A. G. M. (2008). Is pacifier use a risk factor for acute otitis media? A dynamic cohort study. Family Practice, 25(4), 233-6.

Schlueter, N., Amaechi, B. T., Bartlett, D., Buzalaf, M. A. R., Carvalho, T. S., Ganss, C. ... Lippert, F. (2020) Terminology of erosive tooth wear: consensus report of a workshop organized by the orca and the cariology research group of the IADR. Caries Research, 54(1), 2-6.

Silveira, L. C., Charone, S., Maia, L. C., Soares, R. M. A., \& Portela, M. B. (2009). Biofilm formation by Candida species on silicone surfaces and latex pacifier nipples: an in vitro study. The Journal of Clinical Pediatric Dentistry, 33(3), 235-240.

Sio, J. O., Minwalla, F. K., George, R. H., \& Booth, I.W. (1987). Oral candida: is dummy carriage the culprit? Archives of Disease in Childhood, 62(4), 406-8.

Sterzenbach, T., Helbig, R., Hannig, C., \& Hannig, M. (2020). Bioadhesion in the oral cavity and approaches for biofilm management by surface modifications. Clinical Oral Investigations, 24(12), 4237-4260.

Tang, H., Cao, T., Liang, X., Wang, A., Salley, S. O., McAllister, J 2nd., Ng, K. Y. (2009). Influence of silicone surface roughness and hydrophobicity on adhesion and colonization of Staphylococcus epidermidis. Journal of Biomedical Materials Research. Part A, 88(2), 454-63.

Yuan, C., Wang, X., Gao, X., Chen, F., Liang, X., Li, D. (2016). Effects of surface properties of polymer-based restorative materials on early adhesion of Streptococcus mutans in vitro. Journal of Dentistry, 54, 33-40.

Zhou, Z., Liu, F., Shen, S., Shang, L., Shang, L., Wang, X. (2016). Prevalence of and factors affecting malocclusion in primary dentition among children in Xi'an, China. BMC Oral Health, 16(1), 91. 